\title{
Effects of exposure to halothane, isoflurane, and sevoflurane on embryo viability and gestation in female mice
}

\author{
Efeitos da exposição ao halotano, isofluorano, e sevofluorano na \\ viabilidade embrionária e gestação em fêmeas de camundongos
}

\author{
Ademir Cassiano da Rosa ${ }^{1 *}$; Suzane Lilian Beier²; Nilson Oleskovicz ${ }^{1}$; \\ Joana Cláudia Mezzalira ${ }^{3}$; David José Miquelutti4; \\ Alceu Mezzalira ${ }^{1}$; Aury Nunes de Moraes ${ }^{1}$
}

\begin{abstract}
Although the negative effects of inhalation anaesthetics on fertility have been known for a while, the stages during the reproductive cycle at which these effects occur and the mechanisms of action are largely unknown. This study aimed to evaluate the effects of acute exposure of female mice to halothane, isoflurane, and sevoflurane prior to mating. $\mathrm{BALB} / \mathrm{c}$ female mice $(\mathrm{n}=160)$ were allocated in groups of 20 to halothane (HG), isoflurane (IG), sevoflurane (SG), and oxygen/sham (SH) treatment groups and their respective control groups (CGs). The mice were exposed to 1 minimum alveolar concentration (MAC) of the corresponding anaesthetic or oxygen for $4 \mathrm{~h} /$ day over 5 consecutive days. Two days after exposure, females were mated with males (ratio 2:1 female/male) for five consecutive days. Every morning, females were checked for the presence of vaginal plugs. Half of the females that exhibited plugs were euthanised $72 \mathrm{~h}$ later for embryo evaluation. The remaining females were euthanised on the 14th day of pregnancy for foetal evaluation. A low number of morulae and total embryos (morulae + blastocysts) were observed in the HG $(\mathrm{P}<0.05)$. The number of implantations was lower in the HG (6.0) compared with the IG (11.8) and SG (12.4) $(\mathrm{P}<0.05)$. Exposure to halothane is not recommended for use in female mice prior to mating procedures because it leads to decreased embryo production and pregnancy failure. Sevoflurane induces a delay in embryo development, thereby influencing the morulae to blastocyst ratio. Isoflurane is the safest of the tested anaesthetics for use in female mice prior to mating.
\end{abstract}

Key words: Embryo, foetus, gestation, litter size, inhalation anaesthetic

\section{Resumo}

Embora os efeitos negativos dos anestésicos inalatórios na fertilidade já foram descritos há algum tempo, os estágios durante o ciclo reprodutivo em que estes efeitos ocorrem bem como os mecanismos de ação ainda permanecem desconhecidos. Os objetivos deste estudo foram avaliar os efeitos da exposição aguda em fêmeas de camundongos ao halotano, isofluorano, e sevofluorano prévio ao acasalamento.

1 Profs. Drs. of Department of Veterinary Medicine, School of Agriculture and Veterinary Science, Santa Catarina State University, CAV/UDESC, Lages, SC, Brazil. E-mail: cassivetr@hotmail.com; a2no@cav.udesc.br; a2am@cav.udesc.br; aury.moraes@ udesc.br

2 Prof $^{\mathrm{a}} \mathrm{Dr}^{\mathrm{a}}$ of Department of Clinical and Veterinary Surgery, School of Veterinary, Federal University of Minas Gerais, UFMG, Belo Horizonte, MG, Brazil. E-mail: suzanelb@ufmg.br

3 Doctoral student of Department of Veterinary Medicine, School of Agriculture and Veterinary Science, Santa Catarina State University, CAV/UDESC, Lages, SC, Brazil. E-mail: joanamezzalira@yahoo.com.br

4 Prof. Dr. of Department of Land and Natural Resources, School of Agriculture and Veterinary Science, Santa Catarina State University, CAV/UDESC, Lages, SC, Brazil. E-mail: david.miquelluti@udesc.br

* Author for corespondence 
Fêmeas de camundongos BALB/c ( $\mathrm{n}=160)$ foram alocadas em grupos de 20 aos tratamentos halotano (HG), isofluorano (IG), sevofluorano (SG), oxigênio (SH), e seus respectivos grupos controle (CGs). As fêmeas de camundongos foram expostas a uma concentração alveolar mínima (CAM) do anestésico correspondente ou a oxigênio por 4 horas diárias durante 5 dias consecutivos. Após dois dias do fim da exposição às fêmeas foram acasaladas com os machos (proporção 2:1 fêmea/macho) durante 5 dias consecutivos. A cada manhã, as fêmeas foram avaliadas para a observação da presença de plug vaginal. Metade das fêmeas que exibiam plug foram submetidas à eutanásia após 72 horas para avaliação embrionária. As fêmeas restantes foram eutanasiadas no $14^{\circ}$ dia de gestação para avaliação fetal. No HG foi observado um menor número de mórulas e embriões totais (mórulas + blastocistos) $(\mathrm{P}<0,05)$. O número de implantações foi menor no HG $(6,0)$ comparado ao IG $(11,8)$ e SG $(12,4)(\mathrm{P}<0,05)$. A exposição ao halotano não é recomendada para uso em fêmeas de camundongos prévio ao acasalamento, pois leva a diminuição da produção embrionária e falha na gestação. O sevofluorano induz a um atraso no desenvolvimento embrionário, desse modo influenciando na proporção de mórulas e blastocistos. $\mathrm{O}$ isofluorano é o mais seguro dos anestésicos avaliados para uso em fêmeas de camundongos prévio ao acasalamento.

Palavras-chave: Embriões, fetos, gestação, tamanho de ninhada, anestésicos inalatórios

\section{Introduction}

Exposure to inhalation anaesthetic can present a risk for fertility, especially for females exposed during the pre-gestational period. Several studies have demonstrated the toxic effects of occupational exposure to many inhalation anaesthetics in male and female rodents with different species and study designs (PUIG et al., 1999; LEE et al., 1994; CHETKOWSKI; NASS, 1988). However, the effects of exposure to different amounts of inhalation anaesthetics and exposure during different stages of the reproductive cycle have not yet been elucidated.

Women requiring assisted reproductive technology treatment often require anaesthetic during the procedures, including during in vitro fertilisation protocols or embryo transfer procedures (PUIG et al., 1999), and this is sometimes also true for female animals. There are insufficient data to develop recommendations on inhalation anaesthetics in women undergoing such procedures (PUIG et al., 1999), and for animals, no papers on this subject are available in the literature. In small animal veterinary practices, the exposure of female veterinarians to inhalation anaesthetics occurs mainly through leakage of anaesthetic gases from equipment and from around animal face masks (SHIRANGI et al., 2007). Epidemiological and retrospective studies have shown contradictory results regarding the effects of chronic occupational exposure to inhalation anaesthetics. Some studies have shown that exposure may be harmful, producing teratogenic effects (VAISMANN, 1967; BERGHAUS et al., 1999), immunologic effects (VAISMANN, 1967; EGER 2005), reproductive failures and miscarriages (VAISMANN, 1967), organ toxicity (VAISMANN, 1967; BERGHAUS et al., 1999), carcinogenic effects (EGER, 2005; COATE et al., 1979), and learning delays in offspring (LI et al., 2007).

A pioneering study (VAISMANN, 1967) evaluated the health status of 308 anaesthesiologists (198 males and 110 females) who used diethyl ether, nitrous oxide, and halothane on a daily basis and found that these professionals exhibited symptoms, such as headache, fatigue, and irritability. The same study also highlighted, for the first time, the adverse effects of these anaesthetics on human reproduction; 18 of 31 anaesthesiologists who were pregnant during the study experienced miscarriages.

Of the fluorinated inhalation anaesthetics, which are commonly used, only halothane and isoflurane have been studied. Reproductive effects from different anaesthetic levels were evaluated in rats and mice exposed to halothane (KENNEDY et al., 1976; WHARTON et al., 1978), and no negative effects were observed, although exposure to high 
levels resulted in skeletal abnormalities in the offspring (WHARTON et al., 1978; BUSSARD et al., 1974). When isoflurane exposure in mice was performed before gestation, no negative effects were observed (MAZZE, 1985). The effects of the newest inhalation anaesthetics that have been introduced into clinical practice with appropriate pharmacokinetic characteristics, such as sevoflurane, have been evaluated, but information on their safety remains scarce. Exposure to sevoflurane for $8 \mathrm{~h}$ in mice during pregnancy caused cleft palate in foetuses, although with a lower incidence compared with the incidence resulting from halothane exposure (NATSUME et al., 1990). Additionally, lower semen quality was observed in rabbits chronically exposed to sevoflurane (CEYHAN et al., 2005).

The main objective of this study was to assess the effects of pre-gestational exposure of female mice to three of the most commonly used inhalational anaesthetics (i.e., halothane, isoflurane, and sevoflurane) on the number and viability of embryos and foetuses; foetal teratogenesis was also assessed.

\section{Materials and Methods}

This study was approved by the Animal Welfare and Ethics Committee under protocol no. 1.30/06.

\section{Animals}

BALB/c female mice aged 8 to 12 wks $(n=160)$ and adult male mice $(n=40)$ were used in these experiments. The animals were maintained under controlled conditions, which included a $12 \mathrm{~h}$ light/12 $\mathrm{h}$ dark cycle and temperatures between 20 and $24^{\circ} \mathrm{C}$. Ten females were kept in each polypropylene box (40 ' $20^{\prime} 15 \mathrm{~cm}$ ) with wood shavings as bedding, while males were maintained in individual boxes $\left(20^{\prime} 15^{\prime} 15 \mathrm{~cm}\right)$. Commercial feed (Supralab®, Alisul alimentos S.A., Itajai, Santa Catarina, Brazil) and water were available ad libitum.

\section{Anaesthetic drugs}

Halothane (Tanohalo) ${ }^{\circledR}$, isoflurane (Isoforine) ${ }^{\circledR}$, and sevoflurane (Sevocris) ${ }^{\circledR}$ were purchased from Cristália produtos químicos e terapeuticos Ltda, Itapira in São Paulo, Brazil.

\section{Experimental design}

The female mice were allocated to the following four experimental groups: oxygen/sham group (SH), halothane group (HG), isoflurane group (IG), and sevoflurane group (SG). For each experimental group, there was a control group of 20 females that were housed and treated similarly to the treatment groups but were not submitted to anaesthetic or oxygen treatments.

\section{Exposure to anaesthetics/oxygen procedures}

Groups of 20 females were exposed at one time, and exposure was carried out for 5 consecutive days. Exposure took place in a $40^{\prime} 40^{\prime} 10-\mathrm{cm}$ acrylic anaesthetic chamber. The chamber had a single orifice for entry and exit of anaesthetic gases and oxygen. Controlled ventilation in combination with a gas analyser (DX 2010®, Dixtal Medical, Wallingford, USA) allowed assessment of the amount of gases to which the animals were exposed throughout the exposure period. A sidestream capnograph was coupled to the gas entry/exit orifice and a gas analyser with a multiparameter monitor. A unidirectional valve positioned upstream from the gas analyser was joined to a corrugated tube, which was used for administration of oxygen and inhalational anaesthetics. Another corrugated tube was coupled to the valve's exit orifice to remove the gases from the experimental chamber.

An oxygen monitor (Ohmeda ${ }^{\circledR} 5120$ oxygen monitor, BOC health care, USA) was coupled to the unidirectional valve for assessment of the fraction of inspired oxygen (FiO2). The inhalational anaesthesia device (Takaoka ${ }^{\circledR}$ conjunto KT-10, 
Takaoka indústria e comércio Ltda, São Bernardo do Campo, São Paulo, Brazil) provided an oxygen flow rate of $2 \mathrm{~L} / \mathrm{min}$.

Controlled ventilation was sustained using paediatric bellows (Fole pediátrico $100 \mathrm{ml}$ Takaoka ${ }^{\circledR}$, Takaoka indústria e comércio Ltda, São Bernardo do Campo, São Paulo, Brazil). Calibrated vaporisers specific to each anaesthetic were used. The exhaled amount of each anaesthetic was monitored and maintained between 1 minimum alveolar concentration (MAC) $\pm 10 \%$ (halothane, $1.33 \%$; isoflurane, $1.66 \%$; sevoflurane, $2.5 \%$ ), as per Sonner et al. (2000). The MAC value of each inhalational anaesthetic was corrected according to the following formula: inhalational MAC ' 660 $\mathrm{mmHg} / 760 \mathrm{mmHg}$, where $660 \mathrm{mmHg}$ corresponds to the mean atmospheric pressure at the location where this study was performed and $760 \mathrm{mmHg}$ corresponds to the atmospheric pressure at sea level. Female mice were maintained under general inhalational anaesthesia $4 \mathrm{~h}$ /day for 5 consecutive days, for a total of $20 \mathrm{~h}$. Treatment of the female $\mathrm{SH}$ group was performed using the same procedure of exposure as that used for the experimental groups (4 h/day for 5 consecutive days) but consisted of only $100 \%$ oxygen without anaesthetics. The room temperature, including the temperature inside the anaesthetic box, was monitored with the thermometer on the multiparameter apparatus and was maintained between 20 and $24^{\circ} \mathrm{C}$ throughout the experiment (Figure 1).

Figure 1. The experimental design included a phase of exposure to inhalation anaesthetic, followed by embryo and foetal evaluations.
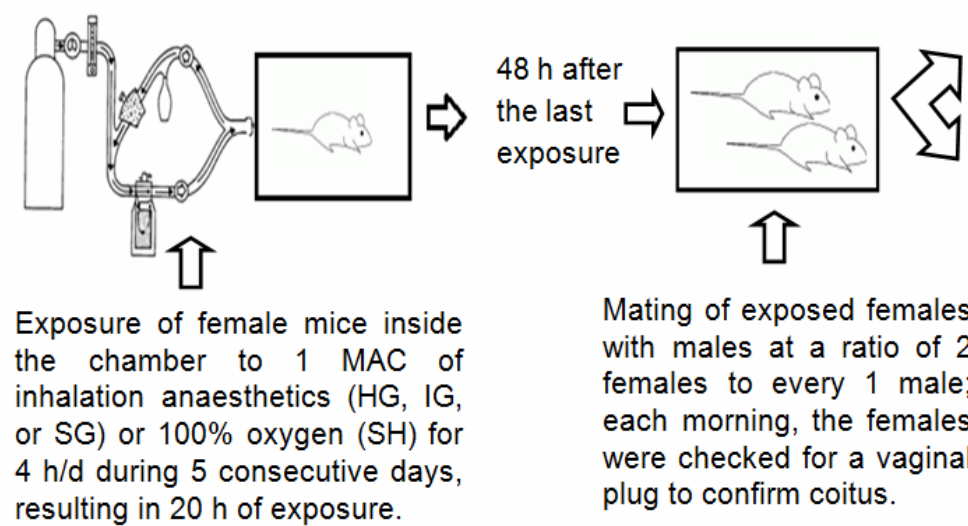

Mating of exposed females with males at a ratio of 2 females to every 1 male; each morning, the females were checked for a vaginal plug to confirm coitus.
$72 \mathrm{~h}$ after plug observation, half of the females were euthanized for embryo evaluation.

The remaining females were euthanized in their $14^{\text {th }}$ day of pregnancy for foetal evaluation.

\section{Female mating and embryo recovery}

After the inhalation procedures, the female mice exposed to anaesthesia and those in the control groups were allowed to rest for $48 \mathrm{~h}$ to avoid possible residual effects from stress caused by the anaesthetic chamber and to allow for the removal of residual anaesthetic. They were then mated with males at a proportion of two females to each male for five consecutive nights. During this period, females were checked every morning for the presence of a vaginal plug (solidified semen), which confirms coitus. The day on which a given female was found to bear a plug was regarded as gestational day 0 . Fifty percent of the females exhibiting a plug were euthanised $72 \mathrm{~h}$ after its detection for embryo collection and evaluation. Females were euthanised by cervical dislocation, and an incision was made in the abdominal wall to dissect and harvest the uterine horns (1Figure 1). 
The uterine horns were placed in Petri dishes containing approximately $0.5 \mathrm{~mL}$ of Dulbecco's phosphate-buffered saline (D-PBS; Stemcell, Science Pro®, São Caetano do Sul, São Paulo, Brazil) containing $10 \%$ foetal bovine serum (Cultilab, Campinas, São Paulo, Brazil). Under a stereomicroscope (Meiji Techno CO. LTD, Tokyo, Japan), each uterine horn was flushed with $1 \mathrm{~mL}$ of D-PBS using a syringe coupled to a needle and inserted into the proximal end of each horn using forceps. The contents of each horn were kept in individual dishes to allow each horn to be individually evaluated.

The number of viable embryos (morulae and blastocysts) and the number of degenerated structures, which included egg cells and cleaved or fragmented embryos, were assessed. The embryos from each experimental group and its respective control group were counted and classified by an experienced professional.

\section{Foetal evaluation}

The remaining females with a detected plug were euthanised on the 14th day of gestation. Females that did not exhibit a vaginal plug during the mating period were also maintained in their boxes and inspected for pregnancy after 14 days. Pregnant females were included in their respective groups (Figure 1).

The number of foetuses and resorptions per female, as well as the foetal size, were assessed, and the external morphologies of the foetuses were observed to check for possible teratogenic anomalies.

Foetal size was measured from the cranium to the insertion of the tail. The liver, lungs, spleen, kidneys, uterus, and ovaries were harvested from the females in all groups and fixed with formaldehyde solution. The same procedure was performed randomly with $20 \%$ of the foetuses from each group. The samples were then sent to Santa Catarina State University Pathology Laboratory for histopathological evaluation.

\section{Statistical analyses}

A comparison between females showing plugs and pregnancy rates was performed using the chi-square test. Comparisons between groups with respect to the numbers of viable embryos, degenerated embryos, foetuses, resorptions, and implantations per female were carried out using general linear models for data exhibiting Poisson and binomial distributions (DOBSON, 2002) with "log" and "logit" link functions, respectively, and analysed using chi-square statistics.

Foetal size was analysed using a linear analysis of variance model, and comparisons between the means of the groups were performed with the Tukey test (STEEL et al., 1997). The analyses were carried out using general linear model (GLM) and generalised linear model (GENMOD) procedures in SAS® version 9.1.3 (2003). The minimum significance level used for all tests was $5 \%$.

\section{Results}

The rate of females showing plugs during the mating period was similar $(\mathrm{P}>0.05)$ in the control $(75 \pm 5.7 \%)$ and anaesthetic $(76 \pm 13.1 \%)$ groups, with lower variation observed in the control groups. On day 3 of the mating period, there were a higher number of females showing plugs in the IG and $\mathrm{SG}$ and their respective control groups. There was a distinct pattern in the HG and its control group, as shown in Table 1. In the HG control group, a higher number of females showing plugs $(n=6)$ was observed on day 2, while in the HG, the peak was delayed to day 5 . 
Table 1. Plug observation during the 5-d mating period for female mice in the control groups or for those submitted to halothane (HG), isoflurane (IG), sevoflurane (SG), or oxygen sham (SH) treatments for $5 \mathrm{~d}$.

\begin{tabular}{ccccccc}
\hline & Day $\mathbf{1}$ & Day $\mathbf{2}$ & Day $\mathbf{3}$ & Day $\mathbf{4}$ & Day $\mathbf{5}$ & Total $^{*}$ \\
HG & 3 & 3 & 2 & 5 & 0 & 13 \\
HG Control & 1 & 6 & 3 & 4 & 0 & 14 \\
IG & 7 & 2 & 5 & 1 & 1 & 16 \\
IG Control & 3 & 1 & 9 & 0 & 1 & 14 \\
SG & 2 & 5 & 7 & 3 & 0 & 17 \\
SG Control & 3 & 2 & 5 & 4 & 2 & 16 \\
SH & 3 & 5 & 2 & 2 & 1 & 13 \\
SH Control & 2 & 3 & 5 & 5 & 1 & 16 \\
\hline
\end{tabular}

* The total number of plugs was not different between the groups $(\mathrm{P}<0.05)$.

The pregnancy rate of mated (showing plugs) females was lower $(\mathrm{P}<0.05)$ in the $\mathrm{HG}(54 \%, 7 / 13)$ than in the SG $(100 \%, 16 / 16)$ and IG $(100 \%, 17 / 17)$. No differences were observed between the control groups $(93.5 \%, 56 / 60)$ and the SH group $(100 \%$, $13 / 13)$, demonstrating that maintaining the females in the anaesthetic chamber did not influence embryo and foetal development. Furthermore, there were no differences between any of the control groups with respect to evaluations of the embryos, gestations, and foetuses. Therefore, we assume that even though the treatments were performed sequentially, they can be compared. Embryo evaluation revealed a lower number of viable morulae in the $\mathrm{HG}(\mathrm{P}<0.05)$. The total number of embryos (morulae + blastocysts) was lower in the HG $(\mathrm{P}<0.05)$, as shown in Table 2. However, there were no differences between the HG, SG, SH, SG control, and SH control. In the $\mathrm{HG}$, of the seven females showing vaginal plugs, three had only degenerated embryos in the uterus. This finding was not observed in any other group.

As demonstrated in Table 2, the number of viable embryos $(\mathrm{n}=26)$ in the HG was lower $(\mathrm{P}<0.05)$ than that in the HG control $(n=60)$, but this reduction was observed only in morulae structures ( 7 vs. 41 , $\mathrm{P}<0.05)$.

Table 2. Mean numbers $( \pm \mathrm{SD})$ and ratios of morulae and blastocysts $(\mathrm{Mo} / \mathrm{Bl})$, as well as degenerated/retarded embryos, from female mice subjected to halothane (HG), isoflurane (IG), sevoflurane (SG), and oxygen sham (SH) treatments compared with each control group.

\begin{tabular}{lccccccc}
\hline Groups & $\begin{array}{c}\text { Females } \\
(\mathbf{n})\end{array}$ & $\begin{array}{c}\text { Mo } \\
(\mathbf{n})\end{array}$ & $\begin{array}{c}\text { BI } \\
(\mathbf{n})\end{array}$ & \multicolumn{2}{c}{$\begin{array}{c}\text { Morulae and Blastocysts } \\
\text { Total Means Ratio }\end{array}$} & $\begin{array}{c}\text { Degenerated/ } \\
\text { Retarded Embryos }\end{array}$ \\
\hline HG & 6 & $7^{\mathrm{a}}$ & $19^{\mathrm{a}}$ & 26 & $4.3 \pm 5.4^{\mathrm{a}}$ & 0.4 & $3.0 \pm 4.3^{\mathrm{a}}$ \\
HG Control & 7 & $41^{\mathrm{b}}$ & $19^{\mathrm{a}}$ & 60 & $8.6 \pm 3.3^{\mathrm{b}}$ & 2.1 & $1.6 \pm 1.8^{\mathrm{a}}$ \\
IG & 9 & $44^{\mathrm{b}}$ & $24^{\mathrm{a}}$ & 68 & $7.5 \pm 3.3^{\mathrm{b}}$ & 1.8 & $0.6 \pm 1.3^{\mathrm{a}}$ \\
IG Control & 7 & $27^{\mathrm{b}}$ & $27^{\mathrm{a}}$ & 54 & $7.7 \pm 3.4^{\mathrm{b}}$ & 1.0 & $0.7 \pm 1.5^{\mathrm{a}}$ \\
SG & 9 & $45^{\mathrm{b}}$ & $10^{\mathrm{a}}$ & 55 & $6.1 \pm 2.5^{\mathrm{ab}}$ & 4.5 & $1.5 \pm 1.6^{\mathrm{a}}$ \\
SG Control & 8 & $24^{\mathrm{b}}$ & $23^{\mathrm{a}}$ & 47 & $5.9 \pm 3.3^{\mathrm{ab}}$ & 1.0 & $1.4 \pm 1.6^{\mathrm{a}}$ \\
SH & 7 & 29 & 19 & 48 & $6.8 \pm 4.5^{\mathrm{ab}}$ & 1.5 & $1.7 \pm 2.6^{\mathrm{a}}$ \\
SH Control & 8 & 30 & 17 & 47 & $5.9 \pm 3.8^{\mathrm{ab}}$ & 1.7 & $1.4 \pm 2.5^{\mathrm{a}}$ \\
\hline
\end{tabular}

${ }^{\text {ab }}$ Different letters in the same column indicate significant differences $(\mathrm{P}<0.05)$. 
Isoflurane and sevoflurane did not influence the number of viable or degenerated embryos compared with these numbers in their respective control groups. However, sevoflurane influenced the morula/blastocyst ratio presented in Table 2 . As previously observed in the embryo evaluations, there were fewer females in the HG exhibiting plugs (4/7) $(\mathrm{P}<0.05)$ than in the IG (8/8), SG (8/8), and SH (6/6). Additionally, the $\mathrm{HG}$ exhibited the smallest foetuses (10 mm) compared with the other groups $(\mathrm{P}<0.05)$, as shown in Table 3. The number of implantations per female was lower in the HG $(6.0 \pm 5.7)$ than in the
IG (11.8 \pm 2.6$),$ SG (12.4 \pm 2.9$)$, and SH (10.2 \pm 2.5$)$ $(\mathrm{P}<0.05)$. The number of foetuses per female was lower in the HG (5.28 \pm 5.2$)$ compared with the other groups. However, there were no differences in mean resorptions between all the groups, as shown in Table 3. Foetal malformations were not observed. Histopathological evaluation revealed normal morphology of all structures (liver, lungs, spleen, kidneys, uterus, and ovaries) in females exposed to anaesthetics or the oxygen sham ( $\mathrm{SH})$ treatment, as well as in females in the control groups. Foetuses from all groups also showed normal histology.

Table 3. Mean values and standard deviations (mean $\pm \mathrm{SD}$ ) of implantations, foetuses, resorptions, and foetal size in female mice exposed to halothane (HG), isoflurane (IG), or sevoflurane (SG) anaesthetic; given an oxygen sham (SH) treatment; or in the control group.

\begin{tabular}{clcccc}
\hline Variables & \multicolumn{1}{c}{ HG } & IG & SG & SH & \multicolumn{1}{c}{ Control } \\
\hline Implantations/female (n) & $6.0 \pm 5.7^{\mathrm{a}}$ & $11.8 \pm 2.6^{\mathrm{b}}$ & $12.4 \pm 2.9^{\mathrm{b}}$ & $10.2 \pm 2.5^{\mathrm{b}}$ & $9.9 \pm 5.2^{\mathrm{b}}$ \\
Foetuses/female (n) & $5.28 \pm 5.2^{\mathrm{a}}$ & $10.6 \pm 3.7^{\mathrm{b}}$ & $10 \pm 2.6^{\mathrm{ab}}$ & $8.7 \pm 2.1^{\mathrm{ab}}$ & $8.1 \pm 4.7^{\mathrm{ab}}$ \\
Resorptions/female (n) & $0.7 \pm 1.2^{\mathrm{a}}$ & $1.2 \pm 2^{\mathrm{a}}$ & $2.4 \pm 2.2^{\mathrm{a}}$ & $1.5 \pm 0.8^{\mathrm{a}}$ & $1.9 \pm 2.4^{\mathrm{a}}$ \\
Foetal size (mm) & $10 \pm 1.2^{\mathrm{a}}$ & $11.8 \pm 0.5^{\mathrm{c}}$ & $11.2 \pm 0.8^{\mathrm{b}}$ & $10.8 \pm 1.0^{\mathrm{b}}$ & $11.1 \pm 0.75^{\mathrm{b}}$ \\
\hline
\end{tabular}

${ }^{\mathrm{abc}}$ Different letters in the same row indicate significant differences $(\mathrm{P}<0.05)$.

\section{Discussion}

The doses, duration, and time of anaesthetic treatments in relation to the mating time were based on previous studies carried out with rodents (PUIG et al., 1999; MAZZE, 1985; MAZZE et al., 1986; FUJINAGA et al., 1987; WHARTON et al., 1978, 1979). However, this study was performed in the pre-gestational period, in contrast to the gestational period exposure performed in the studies cited above.

The differences in the anaesthetic potency of halothane (1.33 MAC), isoflurane (1.66 MAC), and sevoflurane (2.5 MAC) in mice (SONNER et al., 2000) are suggested to be responsible for the differences in animal responses. Our data showed that halothane exposure was detrimental for embryo and foetal development in female mice. The harmful effects of halothane were also reported in studies with Chinese hamster fibroblasts (STURROCK,
1975), fava beans (GRANT et al., 1974), and fruit fly embryos (KUNDOMAL; BADEN, 1985). Halothane has an inhibitory effect on dividing cells, as demonstrated by Sturrock (1975), who observed a delay in mitosis in Chinese hamster fibroblasts. The same effect was observed by Grant et al. (1974) in fava beans exposed to halothane. Similarly, in this study, exposure to halothane impaired embryonic development (especially the early stages of development of the morulae and blastocysts) and reproductive performance up to a week after treatment. Consequently, the studies mentioned above are in agreement with our results. Even when exposed before mating, the halothane exposure induced a delay in the appearance of plugs in females. Halothane has higher hepatic metabolisation $(20 \%)$ compared with sevoflurane $(2-5 \%)$ or isoflurane $(0.2 \%)$ (EGER, 2005) and therefore induces large amounts of metabolites, which take several days to be eliminated by the organism (PUIG et al., 1999). 
The short 2-d interval between the anaesthetic exposure and mating period may have influenced female responses and could explain the delayed appearance of plugs in the HG. Halothane reduced the mean number of viable embryos, but only in morulae rate, suggesting that embryos of delayed development (i.e., from the precocious morulae stages) were more affected by halothane exposure than the more advanced-stage embryos (blastocysts). However, despite showing a higher absolute number of degenerated embryos, the HG was not different from the other groups (Table 2).

There are no studies demonstrating the mechanism of negative effects of halothane and other halogenated anaesthetics on reproductive activity as described, for example, for nitrous oxide (FUJINAGA, 2001). There is a consensus that the harmful reproductive effects observed due to exposure to inhalation anaesthetics are caused by physiological changes associated with anaesthesia, rather than by the inherent properties of the anaesthetics themselves (MARTIN; NJOKU, 2005). However, there are many reports of low reproductive performance after halothane exposure, such as ovulation failure, production of nonviable oocytes, fertilisation or implantation failure, and early postimplantation embryonic wastage (WHARTON et al., 1978, 1979; KUNDOMAL; BADEN, 1985; MAZZE et al., 1986; CHETKOWSKI; NASS, 1988). The physiological process of pregnancy maintenance could be affected due to cytokine reduction after halothane exposure (MARKOVIC et al., 1993; PUIG et al., 1999).

However, our data showed that halothane exposure did not negatively affect embryonic implantation and post-implantation development in female mice. The mean number of embryos (4.3) obtained from the females used for embryo evaluation was similar to the mean number of foetuses (5.28) obtained from the remaining females in the same group. One theory regarding the mechanism of action of inhalation anaesthetics is that they increase the influx of intracellular $\mathrm{Ca}^{++}$ ions and, consequently, may activate potassium channels that hyperpolarise the cell, potentiate inhibitory GABAergic currents, and depress both calcium channel and excitatory currents (N-methylD-aspartate) via $\mathrm{Ca}^{++}$-dependent mechanisms (GOMEZ; GUATIMOSIM, 2003). $\mathrm{Ca}^{++}$ions have an important role in signalling events, such as egg activation and oocyte maturation, as well as in fertilisation events and other early processes during zygotic development (WEBB; MILLER, 2003; MIAO; WILLIAMS, 2012). The acute exposure to halothane during the 5-d exposure period in our study may have depressed the signalling via $\mathrm{Ca}^{++}$ions and consequently inhibited the early development of the embryos. This depressed signalling is more evident with halothane due to its higher biotransformation (20\%), while elimination of isoflurane and sevoflurane from the organism occurs in their natural forms with negligible biotransformation.

Our study clearly shows that the lower reproductive performance following halothane exposure was the result of a decrease in embryo production, especially in morulae rate. Halothane may also induce embryo degeneration; however, a difference was not observed between the $\mathrm{HG}$ and IG. However, in the HG, three females with vaginal plugs showed only degenerated or retarded embryos, and the same pattern was observed during pregnancy evaluations, with another three females failing to become pregnant. These findings were not observed in the $\mathrm{CG}$, IG, or $\mathrm{SH}$, demonstrating the harmful effects of halothane. As revealed by the lower number of embryos obtained from halothane-treated females, we can infer that halothane influenced the ovulation rate. Because a significant amount of halothane is metabolised in the liver by the cytochrome P450 complex of enzymes (EGER, 2005), there is a link between these compounds and steroid hormone production. During the biosynthesis of steroid hormones from cholesterol, cytochrome P450 enzymes catalyse the hydroxylation and cleavage of the steroid substrate, 
and this reaction is a rate-limiting enzymatic step in the biosynthesis of all steroid hormones (PAYNE; HALES, 2004). This process may affect the surge in luteinising hormone $(\mathrm{LH})$ that precedes ovulation and is triggered by oestrogens and may also affect follicle luteinisation, which is a process that involves the acquisition of steroidogenic competence and expression of cytochrome P450 cholesterol side chain cleavage (RAJKOVIC et al., 2006). However, new and more specific studies are needed to answer this question. In addition to our observations, another study involving halothane exposure in rodents showed a detrimental effect on the formation of the spermatogonial cells (COATE et al., 1979). The exposure of female rats for $12 \mathrm{wks}$ to halothane plus nitrous oxide at concentrations of $113 \mathrm{ppm}+50 \mathrm{ppm}$ or $10 \mathrm{ppm}+500 \mathrm{ppm}$, respectively, decreased oocyte production in both exposure conditions (COATE et al., 1979).

Regarding the gestational evaluation, the $\mathrm{HG}$ exhibited a lower number of foetuses compared with the CG and IG. Our observations are in agreement with a previously reported reduction in the number of foetuses in female mice exposed to halothane at 0.025 to $4 \mathrm{MAC}$ levels/h (simulating chronic exposure) (WHARTON et al., 1978, 1979). Compared with sevoflurane and isoflurane, halothane showed slow anaesthetic recovery and high hepatic metabolisation, which may be potentially responsible for the harmful effects observed.

We also observed smaller foetuses in the $\mathrm{HG}$ compared with the other groups. Bussard et al. (1974) showed that the exposure of pregnant hamsters to $0.6 \%$ halothane plus $60 \%$ nitrous oxide for three hours on the 9 th, $10^{\text {th }}$, or 11 th day of gestation also induced a reduction in weight gain and foetal length, which is in accordance with our observations. In contrast to the HG, the IG and SG showed a similar number of viable and degenerated embryos, suggesting that isoflurane and sevoflurane do not affect early embryo development. This result agrees with a previous report showing similar fertilisation and initial embryonic growth rates for female mice exposed before insemination to nitrous oxide plus 5000 ppm of isoflurane (LEE et al., 1994). Nevertheless, while no reduction in embryos or foetuses was seen, an alteration was observed in the morula/blastocyst ratio in the SG and its CG (4.5 and 1.0, respectively) (Table 2), suggesting a possible delay in embryo development. This result is similar to the findings of Ceyhan et al. (2005), who observed that sevoflurane exposure in male rabbits caused a reduction in semen quality; decreased sperm concentration, motility, and morphology; and negative effects on spermatogenesis. Some studies with isoflurane have been performed using different levels and times (before and during gestation) of exposure (FUJINAGA et al., 1987; MAZZE, 1985) and also yielded similar results regarding the number of foetuses. Differences have also been shown between women working as anaesthetists and other women doctors, with the anaesthetists having a greater incidence of stillbirths, lower birth weights, and congenital malformations (PHAROAH et al., 1977). This result is in agreement with our study, showing that the exposure to anaesthetic gases may be associated with an inhibitory effect on the growth of the foetus. Despite showing harmful effects on embryo and foetal development, neither halothane nor the other tested anaesthetics (i.e., sevoflurane and isoflurane) induced foetal malformations, a finding corroborated by previous studies (MAZZE et al., 1986; WHARTON et al., 1979).

Our data permit us to conclude that exposure to halothane, isoflurane, or sevoflurane anaesthetics prior to the mating period of female mice does not cause an increased incidence of miscarriages or foetal teratogenesis. Halothane exposure before mating induces a delay in the appearance of plugs in female mice, and in mated females, it induces significant pregnancy failure. We also conclude that, of the tested anaesthetics, isoflurane is the safest for use in female mice prior to mating. 


\section{Acknowledgments}

The authors would like to thank "Fundação de Amparo á Pesquisa do Estado de Santa Catarina (FAPESC)" for providing the financial support for this study.

\section{Conflicts of interest}

None of the authors have any conflicts of interest to declare.

\section{References}

BERGHAUS, T. M.; BARON, A.; GEIER, A.; LAMERZ, R.; PAUMGARTNER, G. Hepatotoxicity following desflurane anesthesia. Hepatology, Baltimore, v. 29, n. 2, p. 613-614, 1999.

BUSSARD, D. A.; STELTING, R. K.; PETERSON, C.; ISHAQ, M. Fetal changes in hamsters anesthetized with nitrous oxide and halothane. Anesthesiology, Philadelphia, v. 41, n. 3, p. 275-278, 1974.

CEYHAN, A,; CINCIK, M.; BEDIR, S.; USTUN, H.; DAGLI, G.; KALENDER, H. Effects of exposure to new inhalational anesthetics on spermatogenesis and sperm morphology in rabbits. Archives of Andrology, London, v. 51, n. 4, p. 305-315, 2005.

CHETKOWSKI, R. J.; NASS, T. E. Isofluorane inhibits early mouse embryo development in vitro. Fertility and Sterility, New York, v. 49, n. 1, p. 171-173, 1988.

COATE, W. B.; ULLAND, B. M.; LEWIS, T. R. Chronic exposure to low concentrations of halothanenitrous oxide: lack of carcinogenic effect in the rat. Anesthesiology, Philadelphia, v. 50, n. 4, p. 306-309, 1979.

DOBSON, A. J. An introduction to generalized linear models. $3^{\text {th }}$ ed. Florida: Chapman e Hall, 2008. 320 p.

EGER, E. I. The pharmacology of inhaled anesthetics. Seminars in Anesthesia, Perioperative Medicine and Pain, Orlando, v. 24, n. 2, p. 89-100, 2005.

FUJINAGA, M. Teratogenicity of nitrous oxide. Best Practice and Research Clinical Anesthesiology, Oxford, v. 15 , n. 3, p. 363-375, 2001.

FUJINAGA, M.; BADEN, J. M.; YHAP, E. O.; MAZZE, R. I. Reproductive and teratogenic effects of nitrous oxide, isoflurane, and their combination in SpragueDawley rats. Anesthesiology, Philadelphia, v. 67, n. 6, p. 960-964, 1987.
GOMEZ, R. S.; GUATIMOSIM, C. Mechanism of action of volatile anesthetics: involvement of intracellular calcium signaling. Current Drug Targets - CNS and Neurological Disorders, Hilversum, v. 2, n. 2, p. 123129, 2003.

GRANT, C. J.; POWALL, J. N.; RADFORD, S. G. The effects of halothane on DNA synthesis and mitosis in root tip meristems of Vicia faba. British Journal of Anesthesia, Oxford, v. 46, n. 9, p. 653-657, 1974.

KENNEDY, G. L.; SMITH, S. H.; KEPLINGER, M. L.; CALANDRA, J. C. Reproductive and teratologic studies with halothane. Toxicology and Applied Pharmacology, New York, v. 35, n. 3, p. 467-474, 1976.

KUNDOMAL, Y. R.; BADEN, J. M. Toxicity and teratogenicity of inhaled anesthetics in Drosophila melanogaster. Toxicology Letters, Amsterdam, v. 25, n. 3, p. 287-291, 1985.

LEE, E. J.; BONGSO, A.; KUMAR, A. Evaluation of inhalational anaesthetics on murine in vitro fertilization. Annals of the Academy of Medicine, Singapore, v. 23, n. 4, p. 479-485, 1994.

LI, Y.; LIANG, G.; WANG, S.; MENG, Q.; WANG, Q.; WEI, H. Effects of fetal exposure to isoflurane on postnatal memory and learning in rats. Neuropharmacology, Oxford, v. 53, n. 8, p. 942-950, 2007.

MARKOVIC, S. N.; KNIGHT, P. R.; MURASKO, D. M. Inhibition of interferon stimulation of natural killer cell activity in mice anesthetized with halothane or isoflurane. Anesthesiology, Philadelphia, v. 78, n. 4, p. 620-26, 1993.

MARTIN, J. L.; NJOKU, D. B. Metabolism of modern inhaled anesthetics. In: MILLER, R. D. Miller's anesthesia. $6^{\text {th }}$ ed. London: Churchill Livingstone, 2005. p. 232-272.

MAZZE, R. I. Fertility, reproduction, and postnatal survival in mice chronically exposed to isoflurane. Anesthesiology, Philadelphia, v. 63, n. 6, p. 663-667, 1985.

MAZZE, R. I.; FUJINAGA, M.; RICE, S. A.; HARRIS, S. B.; BADEN, J. M. Reproductive and teratogenic effects of nitrous oxide, halothane, isoflurane, and enflurane in Sprague-Dawley rats. Anesthesiology, Philadelphia, v. 64, n. 3, p. 339-344, 1986.

MIAO, Y. L.; WILLIAMS, C. J. Calcium signaling in mammalian egg activation and embryo development: The influence of subcellular localization. Molecular Reproduction and Development, New York, v. 79, n. 11, p. 742-756, 2012. 
NATSUME, N.; MIURA, S.; SUGIMOTO, S.; NAKAMURA, T.; HORIUCHI, R.; KONDO, S.; FURUKAWA, H.; INAGAKI, S.; KAWAI, T.; YAMADA, M.; ARAL, T.; HOSODA, R. Teratogenicity caused by halothane, enflurane, and sevoflurane, and changes depending $\mathrm{O}_{2}$ concentrations (abstract). Teratology, Philadelphia, v. 42, n. 6, p. 30a, 1990.

PAYNE, A. H.; HALES, D. B. Overview of steroidogenic enzymes in the pathway from cholesterol to active steroid hormones. Endocrine Reviews, Baltimore, v. 25, n. 6, p. 947-70, 2004.

PHAROAH, P. O. D; ALBERMAN, E.; DOYLE, P. Outcome of pregnancy among women in anaesthetic practice. Lancet, London, v. 1, n. 1, p. 34-36, 1977.

PUIG, N. R.; AMERIO, N.; PIAGGIO, E.; BARRAGÁN, J.; COMBA, J. O.; ELENA, G. A. Effects of halothane reexposure in female mice and their offspring. Reproductive Toxicology, Elmsford, v. 13, n. 5, p. 361367, 1999.

RAJKOVIC, A.; PANGAS, S. A.; MATZUK, M. M. Follicular development: mouse, sheep, and human models. In: NEILL, J.D. Knobill and Neill's, physiology of reproduction. $10^{\text {th }}$ ed. Saint Louis: Elsevier, 2006. v. 3, p. 383-423.

STATISTICAL ANALYSIS SYSTEM INSTITUTE SAS. SAS Institute Inc ${ }^{\circledR}$. SAS Ver. 9. 1. 3 SAS Institute Inc.: Cary, North Caroline: Lic. UDESC, 2003.

SHIRANGI, A.; FRITSCHI, L.; HOLMANN, C. D. J. Prevalence of occupational exposures and protective practices in Australian female veterinarians. Australian Veterinary Journal, Victoria, v. 85, n. 1-2, p. 32-38, 2007.
SONNER, J. M.; GONG, D.; EGER, E. I. Naturally occurring variability in anesthetic potency among inbred mouse strains. Anesthesia and Analgesia, Cleveland, v. 91, n. 3, p. 720-726, 2000.

STEEL, R. G. D.; TORRIE, J. H.; DICKEY, D. A. Principles and procedures of statistics - a biomerical approach. $3^{\text {th }}$ ed. New York: McGraw-Hill, 1997. 672 p.

STURROCK, J. E. Effect of volatile anaesthetics on cell survival as measured by colony forming ability. British Journal of Anaesthesia, Oxford, v. 47, n. 8, p. 831-835, 1975.

VAISMANN,A. I. Working conditions in surgery and their effects on the health of anesthesiologists. Eksperimental naia Khirurgiia i Anesteziologiia, Moskva, v. 12, n. 3, p. 44-49, 1967.

WEBB, S. E.; MILLER, A. L. Calcium signaling during embryo development. Nature Reviews Molecular Cell Biology, London, v. 4, n. 7, p. 539-551, 2003.

WHARTON, R. S.; MAZZE, R. I.; BADEN, J. M.; HITT, B. A.; DOOLEY, J. R. Fertility, reproduction and postnatal survival in mice chronically exposed to halothane. Anesthesiology, Philadelphia, v. 48, n. 3, p. 167-174, 1978.

WHARTON, R. S.; WILSON, A. I.; MAZZE, R. I.; BADEN, J. M.; RICE, S. A. Fetal morphology in mice exposed to halothane. Anesthesiology, Philadelphia, v. 51, n. 6, p. 532-537, 1979. 
